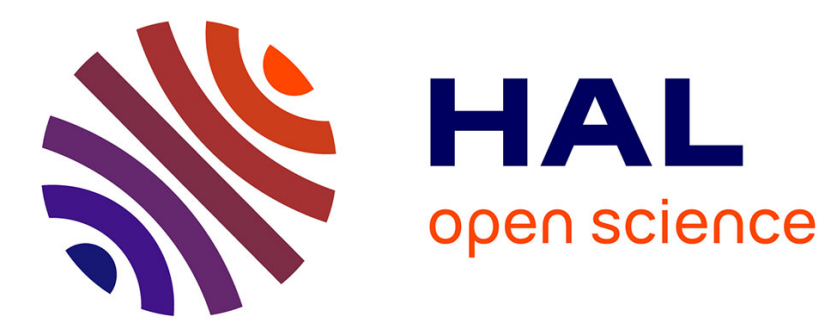

\title{
Exploring the Use of Trade and Professional Association Services
}

\author{
Paul John Alexander Robson, Robert J Bennett
}

\section{To cite this version:}

Paul John Alexander Robson, Robert J Bennett. Exploring the Use of Trade and Professional Association Services. Applied Economics, 2009, pp.1. 10.1080/00036840802599990 . hal-00582228

\section{HAL Id: hal-00582228 \\ https://hal.science/hal-00582228}

Submitted on 1 Apr 2011

HAL is a multi-disciplinary open access archive for the deposit and dissemination of scientific research documents, whether they are published or not. The documents may come from teaching and research institutions in France or abroad, or from public or private research centers.
L'archive ouverte pluridisciplinaire HAL, est destinée au dépôt et à la diffusion de documents scientifiques de niveau recherche, publiés ou non, émanant des établissements d'enseignement et de recherche français ou étrangers, des laboratoires publics ou privés. 


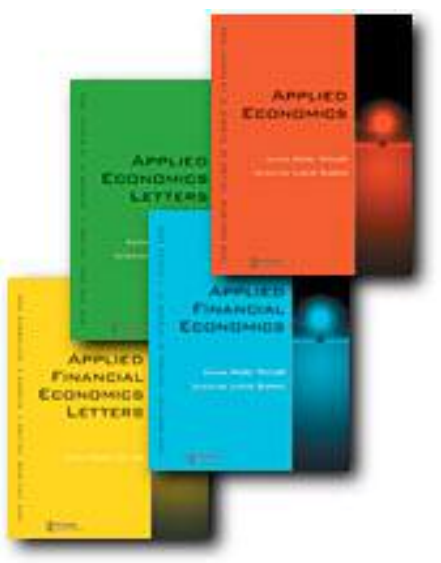

Exploring the Use of Trade and Professional Association Services

\begin{tabular}{|c|c|}
\hline Journal: & Applied Economics \\
\hline Manuscript ID: & APE-07-0159.R1 \\
\hline Journal Selection: & Applied Economics \\
\hline $\begin{array}{r}\text { Date Submitted by the } \\
\text { Author: }\end{array}$ & 23-Aug-2008 \\
\hline Complete List of Authors: & $\begin{array}{l}\text { Robson, Paul; Durham University, Durham Business School } \\
\text { Bennett, Robert; Cambridge University, Geography department }\end{array}$ \\
\hline JEL Code: & $\begin{array}{l}\text { D23 - Organizational Behavior|Transaction Costs|Property Rights }< \\
\text { D2 - Production and Organizations }<\text { D - Microeconomics, L14 - } \\
\text { Transactional Relationships|Contracts and Reputation|Networks }< \\
\text { L1 - Market Structure, Firm Strategy, and Market Performance }<\text { L - } \\
\text { Industrial Organization, L80 - General < L8 - Industry Studies: } \\
\text { Services < L - Industrial Organization }\end{array}$ \\
\hline Keywords: & trade, professional, associations, services \\
\hline
\end{tabular}

\section{ऽ ScholaroNE" \\ Manuscript Central}




\section{Exploring the Use of Trade and Professional Association Services}

\section{Introduction}

Business associations are an important interface for information exchange and lobbying of government. However, the literature on business associations has long recognised a tension between, on the one hand, the collective lobbying function of associations to represent business interests on behalf of their members (the logic of influence), and on the other hand, on the individual benefits that members can receive from their associations (the logic of services) (see e.g. Streeck and Schmitter, 1985; Grant, 1987, 2000; Van Waarden, 1991; Van Schendelen, 1993; Greenwood, 1995; May et al. 1998; Bennett, 1998).

The tension between these two logics can have the effect of reducing the resources and concern that associations exercise for political and collective activities in favour of providing individual services. Olson (1971) recognised the dangers of collective actions becoming sidelined as a by-product of the service activities of associations rather than being their main role, whilst Hirschmann $(1970,1982)$ interpreted the dynamics of associations in terms of the need for association managers to reduce membership exit through providing sufficient mechanisms to allow adequate voice, to inspire loyalty or to stimulate involvement between members and their association in order to retain a focus on the lobbying and representation function.

The literature that has analysed these tensions has recognised that beneath the political activities of associations there must lie an economic rationale that trades-off the costs and benefits. This gap has arisen despite the growing recognition of the importance of associations providing effective service delivery by government. For example, in the UK a "model trade association" was launched in 1996 by the Department of Trade and Industry (DTI, 1996; Berry, 1997). In Europe, the efficiency and effectiveness of trade association management has been the subject of a number of studies by contributors to Greenwood (1995, 2002, 2003). A UK Trade Association Forum has sought to stimulate improvements in trade association management, and has published a best practice guide following the earlier DTI model (see www.taforum.org), drawing on collaborative joint 
work and consultancies with the DTI and supported by CBI (see e.g. MacDonald, 2001). Similarly, the work of Boléat $(1996,1997)$, which has been influential on the Trade Association Forum, has stimulated a stronger focus on association management capacity.

Despite this considerable recent output, there has been little attention devoted to how members actually evaluate their associations, and how systematic differences between associations influence user evaluations. This paper first reassesses how political and economic factors influence the size and service structure of associations. It then uses the results of a survey of small and medium sized firms to assess how members respond to different associations in terms of their level of use and the impact they receive from association services. These user evaluations are then employed to infer how association size and staff resources influence the benefits that members receive.

The associations examined throughout are sector bodies. Since the empirical information on which the paper is based is derived from firms themselves, the associations concerned span a wide spectrum of both trade and professional associations.

\section{The politics and economics of the association services market}

Sector associations in Britain, like those in the US and many other countries, are voluntary organisations that business owners or their manager choose to join or not. Businesses choose to join in order to receive either individual or collective benefits, or both. Associations are one of a range of sources of business service information, advice and representation that can be used by a firm (other main sources are consultants, lawyers and accountants, trade suppliers, customers, government agencies, etc.). The market for associations differs from other business service providers because they provide not just priced services, but also social activities, collective services such as group insurance and purchasing, and the critically important role of lobbying and representing the interests of their members. Hence associations have to satisfy a range of different drivers of their service market. 
Sector associations usually combine individual advisory support services to members with collective services such as representation of collective interests. Their collective action activities are their core service and, in effect, their 'unique selling point'. Their chief market and hence cost advantage should result from using this collective service mission, either to gain presence as a 'brand name capital' to develop their marketing, or to gain economies of scope (chiefly of information) through developing the interconnectedness of their staff skills of collective service provision with their individually tailored advice services (see Schneiberg and Hollingsworth, 1991; Taylor and Singleton, 1993; Bennett, 1996; Jordan and Halpin, 2004; Jones, 2004). Previous analysis has demonstrated that their services generally fall into the field that Wilson and Smith (1996) term Group II services, with low revenue per employee. They are largely 'task-interactive' (Mills and Margulies, 1980) that fill specific and often one-off business needs. Jackson et al. (1995) argue that such services have specific characteristics that relate to the specific buyer: the owner-manager or senior manager of the business. Often the defining characteristics of association services appear to be high human asset specificity, 'brand name capital' offering market access and instant recognition, a level of trust of the service, combined with high interconnectedness of transactions based on knowledge of the sector market and information deriving from the representation function (Schneiberg and Hollingsworth, 1991; Bennett and Robson, 2001; Jones, 2004).

Previous studies of the services supplied by associations have also argued that, as membership bodies, they offer specific benefits as intermediaries between motives of pure market/self interest and collective or political commitment (see e.g. Hollingsworth and Boyer, 1997; May et al. 1998). Associations also contrast with private sector service suppliers since they usually do not seek to create a profit, but trade in some form of equilibrium of income and expenditure which tends to emphasise cost recovery 'for the good of their sector'. This has encouraged the view that an association can, in some cases, deliver more than market systems of client-consultant links because it can draw on elements of social linkage, trust and wider collective relationships (see e.g. Boswell, 1980; Bruyn, 1991; Bennett, 2000; Cassey, 2004). This may offer special advantages to associations because they can bundle collective with individual services, thus reducing the transaction costs of providing advice, and perhaps increasing its applicability and improving its content by employing highly skilled staff who know the sector intimately. 
Hence, the political and social capital within the member-to-member cohesion locked up in a sector may provide a resource that improves the quality not only of the collective but also of the individual services that an association can offer.

This potential for an association to provide combined package suggests that there may be some specific advantages of service 'bundling' that are particularly relevant to associations. First, bundling can combine specific and collective services, thus helping to mitigate any free rider problems (Olson, 1971), whereby firms can benefit from services (such as representation) irrespective of whether they are members or not. Second, bundling can offer service economies of scale and scope, thus seeking to overcome the pressures for fragmentation in the association market. Third, bundling may also raise entry barriers to other associations, or improve the competitiveness of the bundled associations, which could also reduce pressures for fragmentation. Providing two or more bundled services raises market entry costs to other and reduces member search and thus opportunities for others to compete. Fourth, bundling may offer the members an effective 'insurance' option: businesses join an association to provide ready access 'in case' they may need a service and other supports. This motivation has been found relevant in other association studies (Bennett, 1996, 2000; Bratton, et al. 2003). Fifth, bundles should lower client search costs as a result of one-stop shopping, allowing a firm to use the same association to supply a range of needs. Sixth, if customer needs are similar, as they often are within a tightly defined sector, then a bundle may be able to satisfy a wide range of businesses, thus gaining cost advantages. Seventh, there is likely to be an 'environmental' factor, that since most competitor associations have similar dynamics (of having to balance individual and collective service needs), that it is difficult to compete except through bundled products.

The supply of services is also influenced by fixed and variable costs. For most professional and advisory services the main costs are the variable costs of core staff (Mills and Margulies, 1980; Perry, 1992; Kotler and Bloom, 1984; Wilson and Smith, 1996), including the costs of highly specific technical staff. Fixed costs arise from the IT, website and communication systems required for an association to exist at all, costs of any library and documentary sources, rents and any specialist equipment. Variable costs, however, including staff as well as transport and delivery costs, are likely to be the main cost element of the sort of services most associations are likely to provide. 
For each of these costs there is usually a critical threshold of volume that is required to make the support service viable and allow market entry. This depends on the interaction of fixed costs with variable costs across the market of potential demand (of the association's sector), which in turn will be influenced by the level of market penetration by the association: what proportion of the sector businesses are members (see e.g. Phillips et al. 1998). This has been referred to in a number of contexts as the need for a 'critical mass' of both supplier services or resources, and sufficient scale of potential demand and depth of market penetration in order to justify the investment required for service development (see e.g. Chandler, 1990; Harrison, 1997; Bennett, 1993). The critical threshold is likely to vary for different mixes of services supplied, and hence the form of service bundling that occurs.

A key purpose of this paper is to investigate whether trade associations services differ from those of other suppliers in how these costs operate. For example, in a study comparing chambers of commerce, which are locally based business associations, and Training and Enterprise Councils, which between 1990 and 2001 were governmentfinanced suppliers of individual and collective business services, Bratton et al. (2003) found: first, that there was an initial critical size threshold for both bodies at a level of between about one and two staff per thousand businesses in the local market catchment. Second, this size threshold is a relative measure; relative to the size of the business sector. The existence of this threshold has important implications for how effective sector-based trade associations can be in a highly fragmented market. Most trade associations have small membership and few staff. Bennett (1998), for example, found that $74 \%$ of trade associations have less than 200 members, and $34.5 \%$ have less than 30 members, whilst $74 \%$ of professional associations have more than 200 members.

If no threshold exists for sector bodies this may explain some of the difficulties the DTI and Trade Association Forum have experienced in trying to encourage association development. Thus, the existence or not, of a minimum size threshold for the effectiveness of sector associations is an important empirical question which it is sought to answer below.

In addition to a size threshold, Bratton et al. (2003) also found that beyond the threshold there was clear evidence of internal economies of scale with increasing chamber of 
commerce size. There was an increasing probability of using chambers as staff size increased, with a significant nonlinear relationship, indicating internal economies of scale. This can be interpreted as chiefly arising from synergies between services ('bundling'). For managers focused on market penetration and use of chamber services, therefore, bigger is better: market penetration disproportionately increases for every additional staff member (provided that these resources are effectively applied). But for the government-financial Training and Enterprise Councils, Bratton et al. (2003) found that once the size threshold is reached returns to scale are linear with staff size: each government support service thus appears as discrete, with little or no benefits of bundling and internal economies of scale or scope.

Bratton et al. (2003) found that the impact of association services differs from that of their use. Whilst the Training and Enterprise Council continued to show no influence on client impact from increasing staff sizes, chambers of commerce do show a significant influence of staff size on impact, but with a tendency for there to be diseconomies at larger staff sizes. This implies that service impact (as a measure of service quality), can be increased only to a point in size of association. This again would have important implications for the DTI (1996) 'model trade association' and the Trade Association Forum.

For sector associations, there is considerable scope for doubt as to whether bundling or other economic factors encourage greater development of benefits with association size. The evidence quoted earlier demonstrates that the vast majority of sector associations is small, and has been for many years. It appears that the underpinning unique selling point of sector associations is their ability to form and sustain a consensus among members on the sectoral issues that are being represented and the services that they are providing. However, generally, the larger the size of the sector in terms of number of firms, the greater will be the diversity of their members' interests, the greater will be the potential for conflicting issues to emerge, and hence the greater will be the difficulty they have of finding a consensus. This has generally tended to encourage fragmentation into small associations and represents a natural limit to the numerical size of membership, and hence to the scale of the organisation and its management structure (Grant, 1987, 1993, 2000; Olson, 1971; Bennett, 1996; May et al., 1998) and the economic benefits of bundling and economics of scale and scope that can be achieved. 
Despite this phenomenon being recognised for many years, it has not been systematically investigated.

This discussion leads to examination of two main hypotheses in the rest of this paper: First, is there a size threshold which influences the market penetration (level of use) and effectiveness of sector associations? This would suggest that associations have to exceed this threshold in order to be sustainable in competition for their market of members. Second, does the market penetration and effectiveness of associations differ once a size threshold (if any) has been reached: are there non-linear size benefits (economies of scale and scope) as found with chambers of commerce, or does effectiveness take another form?

The associations examined cover the whole spectrum of sector bodies that firms use. They include both trade and professional associations. The fundamental distinction between these bodies is that trade associations tend to have members that are the firm, whilst professional associations have individual firm owners, managers or senior staff as their members. As a result the membership of professional associations is normally much larger than trade associations and their service packages differ, with a stronger role for personal training, certification and insurance services in professional bodies. A distinction between these associations is maintained in the analysis below. However, in terms of staff size and costs, professional and trade associations overlap, so that differences should not be exaggerated. Indeed the empirical analysis demonstrates they are subject to the same forces.

\section{Empirical analysis}

Methodology and survey

This paper focuses on the extent of use and the impact of business sector associations. To assess use and impact levels, the paper utilises the results of a large-scale survey of businesses in Britain undertaken in 1997 by the University of Cambridge ESRC Centre for Business Research (CBR). In the CBR survey the use of advice is defined as that which seeks to meet the strategic objectives of the business over the previous three years. Respondents also rate the impact of that advice in meeting their business objectives on a five-point scale. The sampling frame is drawn from Dunn and Bradstreet 
through contact by mail with telephone chasing. It covers small and medium sized businesses ranging from 1 to 500 employees, 58\% in manufacturing and $42 \%$ in business service sectors; it thus covers the main service market of firms of most relevance to sector associations. From an initial random sampling frame of 9909 firms, there are 2474 respondents, but for the purposes of this paper, respondents who were users of sector associations and give sufficient information on all the required questions number 1909. The response rates and non-responses have been systematically compared by age, employment, turnover, pre-tax profit and legal status, for the total sample and for the questions used in this analysis. There is no significant response or non-response bias which affects our analysis (full details are given in Bullock and Hughes, 1998). This allows the conclusions to be treated as a national representative picture. The CBR data on firms are combined with the character of each membership association derived from a survey of associations (Bennett, 1998). This survey covered all trade and professional associations in Britain, although some non-responses removed that sector from the rest of the analysis.

Many factors influence the use by different businesses of advice from business service organisations. Earlier studies have isolated a range of variables related to the type of firm, particularly its size, as well as the type of supplier of advice (see e.g. Storey, 1994; Robson and Bennett, 2000). In the analysis below we include a range of the variables that control for the type of firm that have been previously found to influence the use and impact of advice. These are the size of the firm (number of employees), its rate of profit, rate of employment growth, its sector, whether it is an exporter, its internal staff skill level, and its innovation record. In addition, a test is made of whether service impact is increased by the association staff having delivered the service by a site visit. The formal definition of these variables is given in the Appendix.

This paper is mainly concerned with the characteristics of the business associations used. The chief variable cost of a professional services organisation is its staff, and the other chief aspects of the economics of the business are mainly driven by staff numbers; as argued above, the size of premises, telephone and communication costs, stationery, IT equipment etc. are all strongly related to staff size in business service industries. Hence, staff size is a major factor included in this study. However, to control the relative level of resources available to a given firm in the context of the size of their 
sector the measure used is staff per 1000 businesses in the sector. In addition, a number of other variables that may potentially describe the character of different associations are also included: the age of the association, the total size of its membership, and whether the association is a trade or professional body.

In the analysis below the results are first presented for use of trade and professional associations, and then for their impact. This is followed by an assessment of the probability of use and impact related to size. Use levels of associations are assessed using a logit model, whilst impact is assessed using an ordered logit model. In estimating these models the sample sizes differ slightly because small numbers of respondents do not respond to all questions. These differences are generally too small to have any influence on the generality of the results.

\section{Use and Impact}

The estimates of the probability of using the business support bodies derive from a logit model where the response variable compares whether or not a firm has used the association for advice in its sector over the last three years. These results are presented in Table 1. Initially this is an exploratory analysis, so we do not expect all variables initially to be significant; we move to a final best estimator later in the discussion.

In Table 1 three models are estimated. Model 1 includes all variables listed in the Appendix. Only three are statistically significant: the age of the firm, its size in terms of number of employees and the type of association (whether it is a trade or a professional body). Although most variables are not significant, their signs (positive or negative) are generally in line with expectations. The probability of using an association as a source of advice and information increases with the age and size of a business, with its profitability, and when it is a growing firm or an innovator. Use of associations is higher for manufacturing than service sectors. Use of associations is less likely the higher the internal skill level available, which is to be expected since less external sources are required. It is, however, surprising that exporters are lower users of associations. 
Concerning association characteristics, use of an association declines with association size, perhaps reflecting the lesser intensity or exclusivity offered. It also declines with association age, perhaps reflecting that older associations are less likely to be seen as a progressive and formal-backing source of advice to firms. The use of associations increases with the relative size of staff as a proportion of the number of firms in the sector, and is higher for professional than trade associations. The dummy variable (LESS70) suggests that use of an association is higher for the very small associations with less than 70 members, which is in line with the results for the variable measuring association membership size.

Various further test estimates on the variables in Model 1 are performed by including each, one at a time, with the three significant variables. One of these estimates is reported in Model 2, which includes the profitability of the firm and the staff size of the association. All these tests show, as in the case of model 2, that no individual variable became significant when the others are removed (except firm age, size and types of association). However, inspecting the correlation co-efficient between the variables shows a high degree of multicolinearity between the age of the respondent firm and its employment size. This is indeed a normal pattern in characteristics of small and medium sized firms. It means that both should not be included in the same estimation equation. Dropping firm age and taking each of other variables results in the final estimator, model 3. This is a highly significant equation explaining association use, based on the employee size of the respondent firm, the staff size of the association per 1000 businesses in the sector, and the type of association (trade or professional). We take this as the final model the way in which the firms in this survey use associations.

Model 3 confirms our key hypothesis that the use of associations will depend chiefly on the resources that it can deploy (in terms of staff). That this influence is higher for professional than trade associations is an important finding, suggesting the view that they deliver more direct market benefits. This confirms the importance of understanding these bodies, whereas most of the previous literature has tended to focus solely on trade associations. The significant variable relating to the characteristics of the firm is its size in terms of number of employees. The effect of employee size is commonly found to be a strong positive correlate of many aspects of firm behaviour, especially in analysis of small and medium sized firms. In this model, use of associations increases with firm 
size, suggesting that the firm's internal management structure, the extent of its staff skills, the degree of its focus or marketing and growth, and the extent of its expenditure on $\mathrm{R} \& \mathrm{D}$ and innovation, are all features of size which tend to increase association use.

This assessment can be taken further by including estimates by the user firms of the impact of the advice they receive from the association they used. Impact is assessed by respondents in the survey on a 5-point scale from 1 (no impact) to 5 (crucial impact). Because of this ordering relationship an ordered logit model is used. This assesses the relation of impact to the variables found significant in model 3. But also an additional variable is added to test whether advice was received as a result of a site visit by association staff or not.

In previous attempts to find explanatory variables for the level of impact deriving from the use of external suppliers of business advice it has been found that there are few significant influences related to the type of firm (see e.g. Robson and Bennett, 2000). This has led to the view that impact of advice is dependent on the nature of specific business problems as they arise that are unique to each firm's trading environment and management structure, rather than being generic to particular types of firms. For our sample, this result is generally confirmed in the estimates in Table 2, with the size of the respondent firm having no significant relationship to impact levels. However, the staff size, types of association, and site visits all significantly influence impact. As with use levels, impact is higher for larger staff size, for professional compared to trade associations, and is higher where site visits have occurred.

\section{Shape of association cost functions}

A major concern of this paper is whether the use and impact of sector associations changes as a linear or non-linear function with the size and resources that an association can deploy, since this will indicate whether bundling and service economies of scale and scope exist. The logit and ordered logit models, estimated above, provide estimates that are general measures of the relation of categorical variables (use, impact) to a range of continuous and categorical explanatory variables. The relationships do not have to be linear in either a logit or ordered logit model. 
In order to assess the possible influence of different cost functions, the shape of the probability function of using an association can be re-estimated for each value of any of the significant explanatory variables (Hosmer and Lemeshow, 1989; Bryman and Cramer, 1990). Our attention focuses on the role of staff size since this is the main association variable of significance that we are interested in. Table 3 shows the probability of using an association as a function of relative staff sizes (per thousand of the sector's business population). The shape of the resulting marginal rate of change in the probability functions per member of staff is shown in Figure 1.

These estimates of the probability function have some profound implications for interpreting the management of associations. There is initially a rising probability of use with number of staff per 1000 local businesses, but the marginal rate of increase begins to decline after about 0.5 staff per thousand member businesses. Table 3 and Figure 1 thus give only slight evidence of there being a minimum critical size threshold for an association to achieve a relatively stable position in terms of market penetration. It appears that associations will be used almost irrespective of their staff size and hence the staff technical expertise on offer. This indeed confirms why so many very small associations continue to survive despite calls by government for merger (DTI, 1996; Berry, 1997). Indeed, there may be no minimum staff size at all since many associations survive on purely voluntary inputs and have no staff. There is no evidence that larger staff sizes offer economics of scale and scope effects. The marginal probability declines to an almost constant low level. This means that once a specific staff size is reached (at about three member of staff per thousand businesses) the increased marginal impact of further staff numbers steadily declines in marginal importance.

Similar conclusions can be drawn from the estimates of the probability of receiving impacts of different magnitude with different staff sizes shown in Tables 4 and 5, with the change in marginal probability shown in Figure 2. The marginal rate of change in probability declines steadily where no site visits are involved, indicating no benefits of bundling and economics of scale and scope. However, Table 5 and Figure 2, for cases where a site visit is involved, show as in figure 1, a very small increase in the marginal rate of change of probabilities of impact up to 0.5 staff per thousand businesses. However, the decline in impact after that point is as rapid as those for no site visit. Hence site visits, as a service support, offer a greater probability of impact, and are 
subject to a minimum size for viability. But in general, our results indicate the general ease of market entry for associations and the small or zero minimum threshold to establish and/or maintain an association. There are thus few major benefits of economies of scale for larger sized associations in terms of the service impact they achieve with their members.

\section{Conclusion and Implications}

This paper has presented one of the first analyses of how use and impact of business associations is influenced by association characteristics and firm type. The paper has particularly focused on the evidence for thresholds of association size, and the role of internal and external economies of scale, as indicators that association managers can use to set realistic targets for market penetration and scale of staff organisation required, as well as what government might use as an indicator of association effectiveness.

The empirical results demonstrate that of many possible influences on associations, most characteristics of the user businesses are usually of little significance. Of course, these results must be set in the context that the analysis is of sector associations, so that the firm's sector is already included in the analysis: firms have self-selected to join those bodies that are most relevant to their sector markets. But once the sector is taken into account, for most purposes, the differences in size of business is the only other characteristic of the firm that significantly influences the take-up of association services. Moreover, no firm characteristics (other than sector) significantly influence the impact received. These results are in line with other studies, which suggest that the impact of most advisory services is problem-specific, not firm-specific. This should be a salutary warning to association managers (and to government policy) that targeting the marketing and development of association services by firm type is unlikely to yield significant benefits.

A major focus of the paper is to assess how the probability of use and impact of associations is influenced by the character of the association itself. The statistical estimates show that it is association staff resources that are the most important explanatory factor and not the age of the association or its absolute number of members. Moreover, these staff resources are best measured as relative factors: staff per thousand 
businesses in the sector. This result is not surprising, and is in line with earlier findings for chambers of commerce and government-financed Training and Enterprise Councils (Bratton et al. 2003).

This has two important implications for debates about association management. The size of resources certainly has some influence on the use and impact of associations on the firms that use them. But the changing marginal probability of the scale of impact and use declines to a small level after a very low threshold of staff size. A size of about 0.5 full time members of staff per thousand businesses is sufficient to achieve significant use and impact levels. Hence, an important implication is that associations should at least seek to achieve that size of resources. This supports the argument of DTI (1996) and the efforts of the Trade Association Forum that a minimum best practice level should be achieved by all associations. But a second implication is that, beyond this size there is a declining rate of improvement in association use and impact. Hence, the argument for amalgamating associations into larger units is not sustained; instead it appears that the market favours a large number of small associations focused on specific sectors.

These results suggest that the internal cost structure of associations is not strongly nonlinear; i.e. after fixed costs have been covered to achieve a viable size, there are few economies of scale and scope which influence variable costs. Indeed the marginal benefit of the association staff declines as association staff size further increases. These findings throw new light on the tension between the logic of representation and the logic of services. They indicate that there is an ability to combine (or 'bundle') these two types of service at small staff scales, which gives associations their market niche, but that the marginal benefits decrease as the associations organisation increases in size. Firms seem to get greatest benefit from small and intimate bodies where a small staff know their sector well and can deal directly with the firm's specific problems. This tends to confirm Hirschman's $(1970,1982)$ interpretation of the concepts of exit, voice, loyalty and involvement. Of course, this is a statistical generalisation: large associations can and do develop for sectors where there is strong internal coherence. But the implication is that, in general, these are the exceptions rather than the common pattern, and that endemic fragmentation of sector associations will continue. 
There are significant differences between trade and professional associations, as indicated by the highly statistically significant dummy variable for association type. This indicates a much higher level of use and level of impact achieved for professional compared to trade associations, all other things being equal. Although the focus of questions used in the survey data in this paper cannot give an explanation of this difference, it is likely that it results from their different membership structures: professional bodies generally have individuals as members, trade bodies have firms. As a result, professional bodies tend to focus more heavily on individual service benefits, whereas trade bodies make an offer to the firm as a whole. The marketing of the latter is more diffuse and difficult to satisfy, as our results suggest. This may indicate that trade bodies need to develop a stronger focus on individual benefits to the owner/manager of their member firms, or their personnel. Our results certainly suggest that in the tension between the logic of services and logic of representation, professional bodies are better able to make an individual service impact.

These results can be compared with similar estimates by Bratton et al. (2003). The estimates here for trade and professional associations show a similar emphasis on the importance of staff resource relative to the scale of their largest membership. But the marginal probability of impact increases only up to 0.5 staff per thousand businesses for trade and professional associations, and mostly for intensive services involving a site visit.

Business associations contrast with the government-backed services (such as Training and Enterprise Councils). For these, once they are established at a minimum size level, it appears that managers will not be able to expand market penetration or impact as a result of increasing staff resources. The crucial decision for managers of government support bodies such as these is, therefore, that once they have achieved minimum scale, after this size, all additional staff costs have to be met by additional government finance if there is a public policy requirement to deliver a larger volume of services; the additional costs will not be defrayed by the market demand for services and the impact they offer.

This paper is a first attempt to link the politics and economics of sector associations using information from their users. Clearly there is considerable further research 
possible on the detailed internal unit costs of association organisation and on how members respond to different service offers. It is hoped that this paper will be a useful stimulus to this further work. 


\section{Definitions of variables}

AGE

Age of firm (in years)

LEMP

Log of number of employees

PREMP

Profitability per employee (£1000s)

GROWTH

The percentage rate of employment growth in the firm during the three previous years

SECTOR Dummy $=1$ if the firm is a manufacturer; 0 for services

EXPORT Dummy $=1$ if the firm is an exporter of goods or services; 0 if not

SKILL

The survey allows a breakdown of the respondent's workforce into the following six occupational groups:

1. managerial

2. technologist, scientists and higher professionals

3. technicians and lower professionals

4. clerical and administrative

5. skilled manual, and

6. semi-skilled and unskilled labour

Skill level is defined as the percentage of the workforce who are employed in the first three occupational groups.

INNOV

Dummy $=1$ if the firm is an innovator. Novel Process Innovators are those firms that have introduced a process innovation which is not only new to the firm but also new to the firm's industry.

STAFF Log of full time equivalent total staff of association per thousand businesses in their sector (Source, Small Business Service, statistics of businesses by size and sector).

ASSTYPE Dummy $=1$ if firm is a professional association; 0 for a trade association.

LESS 70 Dummy $=1$ if membership of association is less than 70 members; 0 otherwise

TAAGE

Age of association (in years)

TAMEMB

Log of number of members of association

SITE

Dummy $=1$ if a site visit was received by the firm; 0 if no site visit. 


\section{References}

Bennett, R.J. (1993) Britain's Chambers of Commerce: A national network development study, Association of British Camber of Commerce, London.

Bennett, R.J. (1996) Can transaction cost economics explain voluntary Chambers of Commerce? Journal of Institutional Theoretical Economics, 152, 654-680.

Bennett, R.J. (1998) Business associations and economic development: re-exploring an interface between state and market, Environment and Planning A, 30, 1367-1387.

Bennett, R.J. (2000) The logic of membership of sectoral business associations, Review of Social Economy, LVIII (1), 19-42.

Bennett, R.J. and Robson, P.J.A. (2001) Exploring the market potential and bundling of business association services, Journal of Services Marketing, 115 (3), 222-239.

Berry, M. (1997) Government's objectives and the 'model' trade association, pp. 59-64 in R.J. Bennett (ed.) Trade associations in Britain and Germany: responding to internationalisation and the EU. Anglo-German Foundation, London and Bonn.

Boléat, M. (1996) Trade Association Strategy and Management, Association of British Insurers, London.

Boléat, M. (1997) Trade associations: facing up to new challenges, pp. 52-58 in R.J. Bennett (ed.) Trade associations in Britain and Germany: responding to internationalisation and the EU. Anglo-German Foundation, London and Bonn.

Boswell, J.S. (1980) Social co-operation in economic systems: a business history approach, Review of Social Economy, 38 (2), 155-178.

Bratton, W.J., Bennett, R.J. and Robson, P.J.A. (2003) Critical mass and economics of scale in the supply of services to business support organisations, Journal of Services Marketing, 17 (7), 730-750.

Bruyn, S.T. (1991) A future for the American Economy: the social market, Stanford University Press, California.

Bryman, A. and Cramer, D. (1990) Qualitative Data Analysis for Social Scientists, Routledge, London.

Bullock, A. and Hughes, A. (1998) Survey design, response bias and sample characteristics in the 1997 CBR SME survey, pp. 125-133 in, A. Cosh and A. Hughes (eds.), Enterprise Britain, University of Cambridge, ESRC Centre for Business Research.

Cassey, T. (2004) Social capital and regional economies in Britain, Political Studies, 52 (1), 96-117.

Chandler, A.D. (1990) Scale and scope: the dynamics of industrial capitalism, Belknapp Press, Cambridge, Mass. 
DTI (1996) A best practice guide for the Model Trade Association, Department of Trade and Industry, London (updated 1999: ww.dti.gov.uk/EAM/MTA/MTAinfo.html)

Grant, W. (ed.) (1987) Business interests, organisational development and private interest government; Walter de Gruyter, Berlin.

Grant, W. (1993) Business and politics in Britain, 2nd edition, Macmillan, London

Grant, W. (2000) Pressure groups, Cambridge University Press, Cambridge.

Greenwood, J. (ed.) (1995) European casebook on business alliances, Prentice Hall, London.

Greenwood, J. (ed.) (2002) The effectiveness of EU Business Associations, Palgrave, Basingstoke.

Greenwood, J. (ed.) (2003) Interest representation in the EU, Palgrave, Basingstoke.

Harrison, B. (1997) Lean and Mean: the changing landscape of corporate power in the age of flexibility, Guildford Press, New York.

Hill, C.J. and Neeley, S.E. (1988) Differences in the consumer decision process for professional vs. generic services, Journal of Services Management, 2 (1), pp. 17-23.

Hirschman, A.O. (1970) Exit, voice and loyalty, Harvard University Press, Cambridge, Mass.

Hirschman, A.O. (1982) Shifting involvements: private interest and public action, Basil Blackwell, Oxford.

Hollingsworth, J.R. and Boyer, R. (eds.) (1997) Contemporary capitalism: the embeddedness of institutions, Cambridge University Press, Cambridge.

Hosmer, D.W. and Lemeshow, S. (1989) Applied Logistic Regression, John Wiley and Sons, New York.

Jackson, R.W., Neidell, L.A. and Lunsford, D.A. (1995) An empirical investigation of the differences in goods and services as perceived by organised buyers, Industrial Marketing Management, 24, 99-108.

Jones, P. (2004) 'All for one and one for all': Transaction cost and collective action, Political Studies, 52 (3), 450-468.

Jordan, G. and Halpin, D. (2004) Olson Triumphant? Recruitment strategies and the growth of a small business organisation, Political Studies, 52 (3), 431-449.

Kotler, P. and Bloom, P.N. (1984) Marketing professional services, Prentice-Hall, Englewood Cliffs, N.J. 
MacDonald, A. (2001) The business of representation in the modern trade association: A report of the Trade Association Forum, Trade Association Forum, London.

May, T.C., McHugh, J. and Taylor, T. (1998) Business representation in the UK since 1979: the case of trade associations, Political Studies, XLVI, 260-275.

Mills, P.K. and Margulies, N. (1980) Towards a pure typology of service organisations, Academy of Management Review, 5 (2), 255-265.

Olson, M. (1971) The logic of Collective Action: Public Goods and the Theory of Groups, Second Edition, Harvard University Press, Cambridge, Mass.

Paun, D. (1993) When to bundle or unbundle products, Industrial Marketing Management, 22, 29-34.

Perry, M. (1992) Flexible production, externalisation and the interpretation of business service growth, Service Industries Journal, 12: 1-16.

Phillips, D., MacPherson, A.D. and Lentnek, B. (1998) The optimum size of a producer service firm facing uncertain demand. Environment and Planning A, 30, 129-142.

Robson, P.J.A. and Bennett, R.J. (2000) The use and impact of business advice by SMEs in Britain: An empirical assessment using logit and ordered logit models, Applied Economics, 32, 1675-1688.

Schneiberg, M. and Hollingsworth, J.R. (1991) Can transaction cost economics explain trade associations? In R.M. Czada and A. Windhoff-Heritier (eds.) Political Choice: Institutions, Rules and the Limits of Rationality, Campus, Frankfurt.

Storey, D.J. (1994) Understanding the small business sector, Routledge, London.

Streeck, W. and Schmitter, P.C. (eds.) (1985) Private interest government: beyond market and state, Sage, London.

Taylor, M. and Singleton, S. (1993) The communal resource: Transaction costs and the solution of collective action problems, Politics and Society, 21 (2), 195-214.

Van Schendelen, M.P.C.M. (1993) National, public and private EC lobbying, Dartmouth, Aldershot.

Van Waarden, F. (1991) Two logics of collective action? Business associations as distinct from trade unions: the problems of associations or organisations, pp. 51-84 in Sadowski, D. and Jacobi, O. (eds.) Employers' Association in Europe: policy and organisation, Nomos, Baden-Baden.

Wilson, T.L. and Smith, F.E. (1996) Business services 1982-1992: growth, industry characteristics, financial performance, Industrial Marketing Management, 25, 163-171. 


\begin{tabular}{lccc}
\hline & Model 1 & Model 2 & Model 3 \\
\hline AGE & $0.004^{*}$ & $0.004^{* *}$ & - \\
LEMP & $0.628^{* * *}$ & $0.438^{* * *}$ & $0.539^{* * * *}$ \\
PREMP & 0.001 & -0.002 & - \\
EXPORT & -0.170 & - & - \\
INNOV & 0.167 & - & - \\
GROWTH & 0.004 & - & - \\
SECTOR & 0.300 & - & - \\
SKILL & -0.001 & - & - \\
TAMEMB & -0.313 & - & - \\
STAFF & 0.001 & 0.001 & $0.179^{* * *}$ \\
TAAGE & -0.002 & - & - \\
ASSTYPE & $0.961^{* *}$ & $0.615^{* * *}$ & $0.551^{* * *}$ \\
LESS70 & 0.244 & - & - \\
\hline Constant & $-1.986^{* * *}$ & $-10.325^{* * *}$ & $1.566^{* * *}$ \\
Log likelihood & -811.5 & -1080.85 & -1172.56 \\
Percentage correctly & 67.12 & 66.86 & 67.31 \\
Pseudo R ${ }^{2}$ & 0.041 & 0.031 & 0.029 \\
N & 1323 & 1765 & 1909 \\
\hline & & & - \\
\hline
\end{tabular}

Table 1: Expectations of seeking advice from a trade or professional association; estimates of coefficients from logit models $(* * * \mathrm{p}<0.01, * * \mathrm{p}<0.05, * \mathrm{p}<0.1)$ 


\begin{tabular}{|l|l|}
\hline & Model 1 \\
\hline LEMP & $\begin{array}{l}0.1416 \\
(0.1172)\end{array}$ \\
\hline STAFF & $0.1114 * * *$ \\
& $(0.0221)$ \\
\hline ASSTYPE & $0.1548 * * *$ \\
& $(0.0367)$ \\
\hline Site Visit & $0.6036^{* * *}$ \\
& $(0.1728)$ \\
\hline Cut 1 & -1.3774 \\
& $(0.2047)$ \\
\hline Cut 2 & 0.5403 \\
& $(0.1944)$ \\
\hline Cut 3 & 2.2650 \\
& $(0.2194)$ \\
\hline Cut 4 & 4.3140 \\
& $(0.3556)$ \\
\hline Log likelihood & -792.65 \\
\hline N & 599 \\
\hline
\end{tabular}

Table 2: The impact on clients of the trade and professional association services they receive. Multivariate estimates of an ordered logit model standard errors in parentheses $(* * * \mathrm{p}<0.01 ; * * \mathrm{p}<0.05 ; * \mathrm{p}<0.1)$.

\begin{tabular}{|c|c|c|}
\hline $\begin{array}{c}\text { No. of staff per } \\
1,000 \text { businesses }\end{array}$ & $\begin{array}{c}\text { Probability of using a trade or } \\
\text { professional association }\end{array}$ & $\begin{array}{c}\text { Change in probability per } \\
\text { member of staff }\end{array}$ \\
\hline 0.1 & 29.29 & - \\
\hline 0.2 & 30.42 & 0.113 \\
\hline 0.5 & 31.95 & 0.510 \\
\hline 1.0 & 33.13 & 0.236 \\
\hline 1.5 & 33.84 & 0.142 \\
\hline 2 & 34.34 & 0.100 \\
\hline 3 & 35.06 & 0.072 \\
\hline 4 & 35.57 & 0.051 \\
\hline 5 & 35.97 & 0.040 \\
\hline 6 & 36.30 & 0.033 \\
\hline 7 & 36.57 & 0.027 \\
\hline
\end{tabular}

Table 3: Probability of using a trade and professional association with different staff sizes.

Notes: These calculations assume average firm size, and the PA Dummy is 0. 


\begin{tabular}{|c|c|c|c|c|c|c|}
\hline $\begin{array}{c}\text { No. of } \\
\text { staff per } \\
1,000 \\
\text { businesses }\end{array}$ & $\begin{array}{c}\text { No } \\
\text { Impact }\end{array}$ & $\begin{array}{c}\text { Slight } \\
\text { Impact }\end{array}$ & $\begin{array}{c}\text { Moderate } \\
\text { Impact }\end{array}$ & $\begin{array}{c}\text { Important } \\
\text { Impact }\end{array}$ & $\begin{array}{c}\text { Crucial } \\
\text { Impact }\end{array}$ & $\begin{array}{c}\text { Change in } \\
\text { probability of an } \\
\text { important or } \\
\text { crucial impact }\end{array}$ \\
\hline 0.1 & 18.35 & 42.12 & 29.10 & 8.96 & 1.48 & - \\
\hline 0.2 & 17.85 & 41.81 & 29.58 & 9.23 & 1.53 & 0.320 \\
\hline 0.5 & 17.21 & 41.38 & 30.22 & 9.59 & 1.60 & 0.143 \\
\hline 1.0 & 16.74 & 41.04 & 30.70 & 9.87 & 1.65 & 0.066 \\
\hline 1.5 & 16.47 & 40.83 & 30.98 & 10.04 & 1.68 & 0.040 \\
\hline 2 & 16.28 & 40.68 & 31.17 & 10.17 & 1.71 & 0.032 \\
\hline 3 & 16.01 & 40.46 & 31.45 & 10.34 & 1.74 & 0.020 \\
\hline 4 & 15.83 & 40.30 & 31.64 & 10.46 & 1.76 & 0.014 \\
\hline 5 & 15.68 & 40.18 & 31.79 & 10.56 & 1.78 & 0.012 \\
\hline 6 & 15.57 & 40.08 & 31.91 & 10.64 & 1.80 & 0.010 \\
\hline 7 & 15.47 & 39.99 & 32.02 & 10.71 & 1.81 & 0.008 \\
\hline
\end{tabular}

Table 4: Probability of impacts of external advice (without a site visit) from trade and professional associations at various staff sizes.

Notes: The calculations assume average firm size, the PA Dummy is 0 , and no site visit (i.e. visit dummy is 0 ).

\begin{tabular}{|c|c|c|c|c|c|c|}
\hline $\begin{array}{c}\text { No. of } \\
\text { staff per } \\
1,000 \\
\text { businesses }\end{array}$ & $\begin{array}{c}\text { No } \\
\text { Impact }\end{array}$ & $\begin{array}{c}\text { Slight } \\
\text { Impact }\end{array}$ & $\begin{array}{c}\text { Moderate } \\
\text { Impact }\end{array}$ & $\begin{array}{c}\text { Important } \\
\text { Impact }\end{array}$ & $\begin{array}{c}\text { Crucial } \\
\text { Impact }\end{array}$ & $\begin{array}{c}\text { Change in } \\
\text { probability of an } \\
\text { important or } \\
\text { crucial impact }\end{array}$ \\
\hline 0.1 & 10.95 & 34.60 & 36.89 & 14.89 & 2.67 & - \\
\hline 0.2 & 10.62 & 34.09 & 37.23 & 15.30 & 2.76 & 0.411 \\
\hline 0.5 & 10.21 & 33.41 & 37.66 & 15.84 & 2.88 & 0.418 \\
\hline 1.0 & 9.91 & 32.89 & 37.96 & 16.26 & 2.98 & 0.104 \\
\hline 1.5 & 9.73 & 32.59 & 38.14 & 16.51 & 3.04 & 0.062 \\
\hline 2 & 9.61 & 32.37 & 38.26 & 16.69 & 3.08 & 0.040 \\
\hline 3 & 9.44 & 32.06 & 38.42 & 16.94 & 3.14 & 0.030 \\
\hline 4 & 9.32 & 31.84 & 38.53 & 17.12 & 3.18 & 0.018 \\
\hline 5 & 9.23 & 31.67 & 38.62 & 17.27 & 3.21 & 0.017 \\
\hline 6 & 9.16 & 31.53 & 38.69 & 17.38 & 3.24 & 0.014 \\
\hline 7 & 9.10 & 31.42 & 38.75 & 17.48 & 3.26 & 0.012 \\
\hline
\end{tabular}

Table 5: Probability of impacts of external advice combined with a site visit from trade and professional associations at various staff sizes.

Notes: The calculations assume average firm size, the PA Dummy is 0 , and a site visit (i.e. visit dummy is 1 ). 


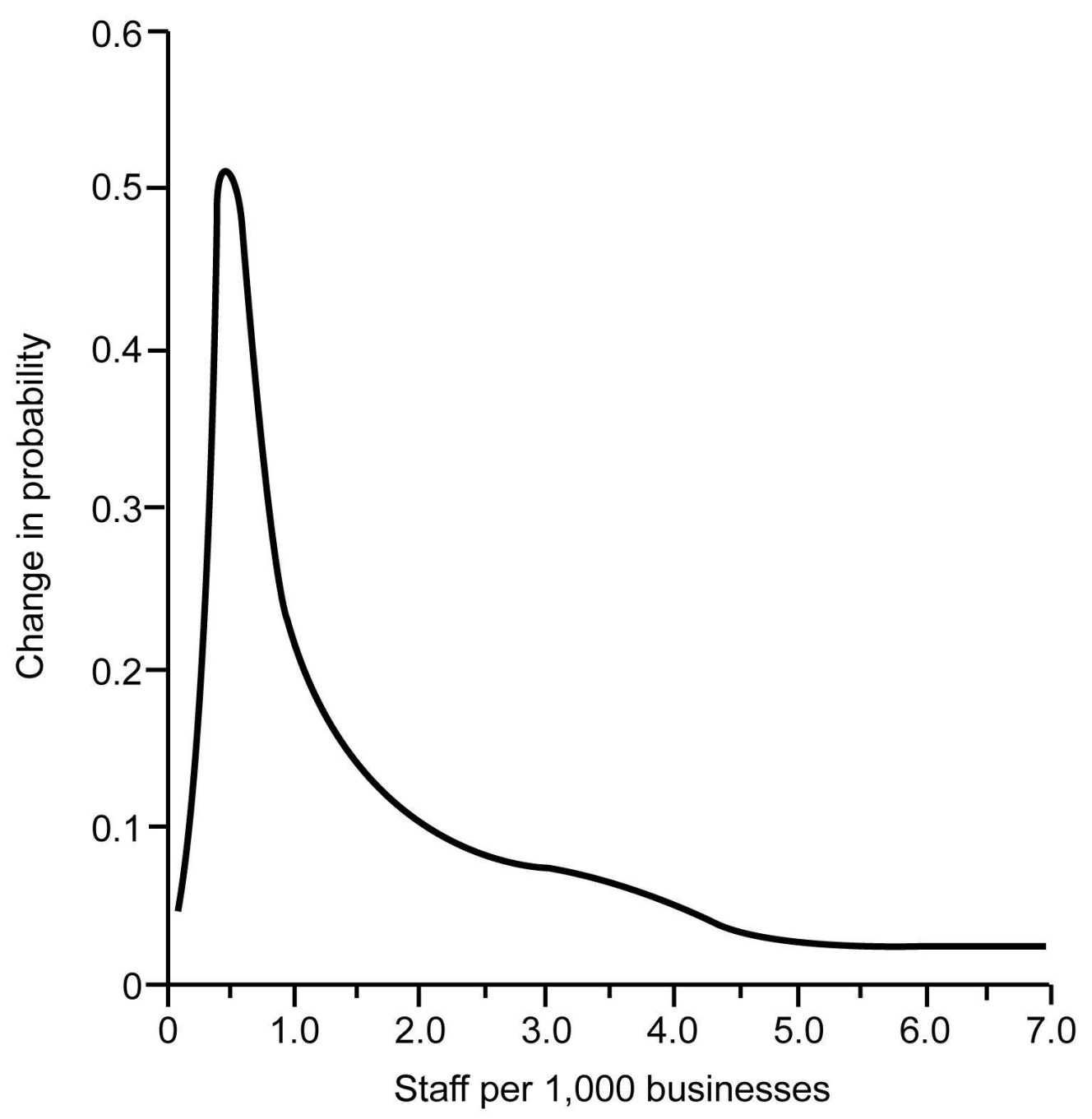

Figure 1: Marginal increase in predicted probability of using a business association for each additional staff member per 1000 businesses in their sectors. (The probability levels are estimated from the logit model 3 in Table 1)

$86 \times 89 \mathrm{~mm}(440 \times 440$ DPI) 


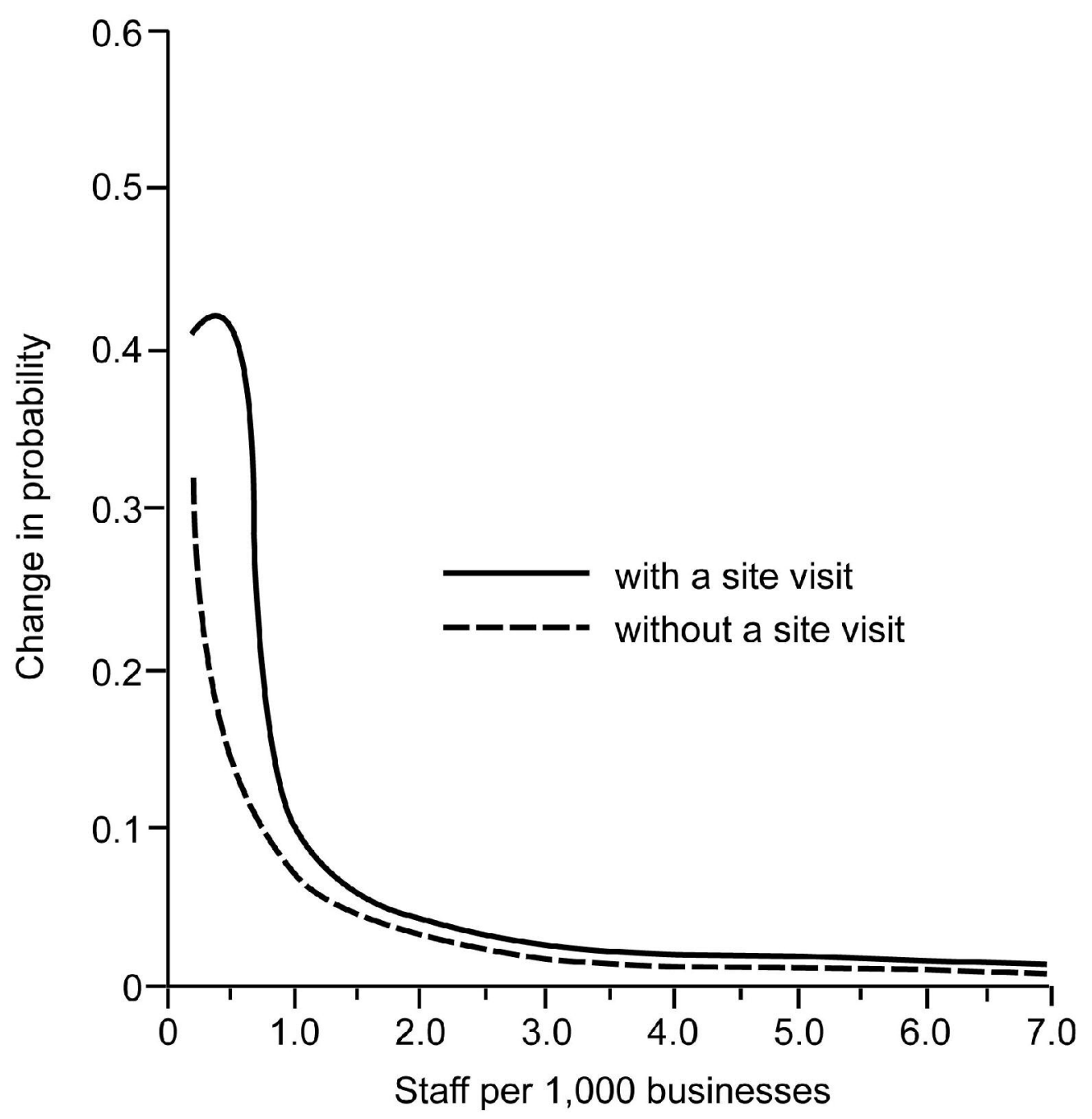

Figure 2: Marginal increase in predicted probability of the impact a business association for each additional staff member per 1000 businesses in their sectors. (Probabilities calculated from the ordered logit model in Table 2 ). $102 \times 105 \mathrm{~mm}(440 \times 440 \mathrm{DPI})$ 